Journal of Biotechnology and Strategic Health Research

\author{
Araştırma Makalesi / Research Article
}

http://dergipark.org.tr/tr/pub/bshr

\title{
Evaluation of Vitamin D Levels in Chronic Hepatitis B Patients
}

\author{
Kronik Hepatit B Hastalarında Vitamin D Düzeylerinin Değerlendirilmesi
}

\section{(iD $₫$ Fatma Meral İnce ${ }^{1}$, (D) Mustafa Kemal Çelen², (D) Hasan İnce ${ }^{3}$, (D) İrem Akdemir Kalkan ${ }^{4}$}

${ }^{1}$ Diyarbakır Selahaddin Eyyubi Devlet Hastanesi, Enfeksiyon Hastalıkları ve Klinik Mikrobiyoloji, Diyarbakır.

${ }^{2}$ Dicle Üniversitesi Tip Fa kültesi, Diyarbakır.

${ }^{3}$ Diyarbakır Selahaddin Eyyubi Devlet Hastanesi, İç Hastalıkları, Diyarbakır.

${ }^{4}$ Ankara Üniversitesi Tip Fakültesi, Ankara

ORCID ID: Fatma Meral İnce https://orcid.org/0000-0003-3429-4169, Mustafa Kemal Çelen https://orcid.org/0000-0001-5876-2241, Hasan İnce https://orcid.org/0000-0003-4879-480X, İrem Akdemir Kalkan https://orcid.org/0000-0001-5136-9148

^Sorumlu Yazar / Corresponding Author: Arzu Altunçekiç Yıldırım, e-posta / e-mail: arzaltu@gmail.com

Geliş Tarihi / Received : 04-01-2021 Kabul Tarihi / Accepted: 27-02-2021 Yayın Tarihi / Online Published: 30-04-2021

İnce F.M., Çelen M.K., İnce H., Akdemir Kalkan İ. Kronik Hepatit B Hastalarında Vitamin D Düzeylerinin Değerlendirilmesi,

J Biotechnol and Strategic Health Res. 2021;5(1):57-64

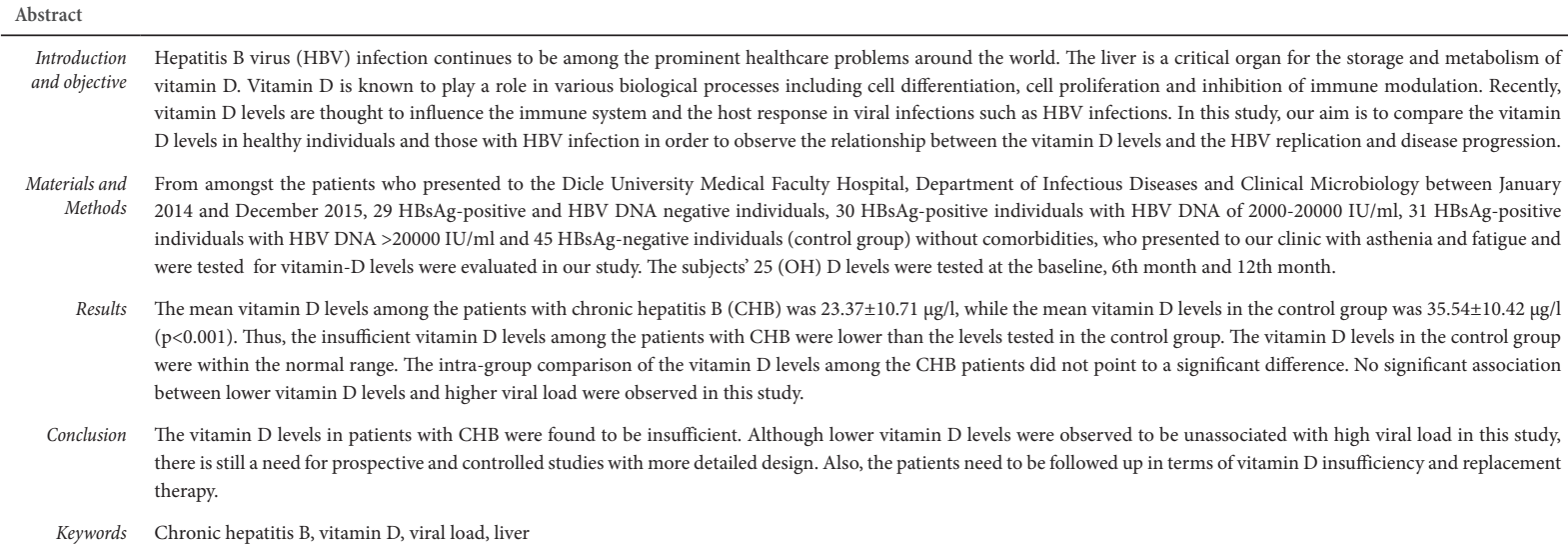
vitamin D levels are thought to influence the immune system and the host response in viral infections such as HBV infections. In this study, our aim is to compare the vitamin D levels in healthy individuals and those with HBV infection in order to observe the relationship between the vitamin D levels and the HBV replication and disease progression.

Materials and From amongst the patients who presented to the Dicle University Medical Faculty Hospital, Department of Infectious Diseases and Clinical Microbiology between January

Methods 2014 and December 2015, 29 HBsAg-positive and HBV DNA negative individuals, 30 HBsAg-positive individuals with HBV DNA of 2000-20000 IU/ml, 31 HBsAg-positive individuals with HBV DNA $>20000 \mathrm{IU} / \mathrm{ml}$ and $45 \mathrm{HBsAg}$-negative individuals (control group) without comorbidities, who presented to our clinic with asthenia and fatigue and were tested for vitamin-D levels were evaluated in our study. The subjects' $25(\mathrm{OH}) \mathrm{D}$ levels were tested at the baseline, 6th month and 12th month.

Results The mean vitamin D levels among the patients with chronic hepatitis B (CHB) was $23.37 \pm 10.71 \mu \mathrm{g} / \mathrm{l}$, while the mean vitamin D levels in the control group was $35.54 \pm 10.42 \mu \mathrm{g} / \mathrm{l}$ $(\mathrm{p}<0.001)$. Thus, the insufficient vitamin D levels among the patients with CHB were lower than the levels tested in the control group. The vitamin D levels in the control group were within the normal range. The intra-group comparison of the vitamin D levels among the CHB patients did not point to a significant difference. No significant association between lower vitamin $\mathrm{D}$ levels and higher viral load were observed in this study.

Conclusion The vitamin D levels in patients with CHB were found to be insufficient. Although lower vitamin D levels were observed to be unassociated with high viral load in this study, there is still a need for prospective and controlled studies with more detailed design. Also, the patients need to be followed up in terms of vitamin D insufficiency and replacement therapy.

Keywords Chronic hepatitis B, vitamin D, viral load, liver

Özet

Amac Hepatit B virüs (HBV) enfeksiyonu halen tüm dünyada önde gelen sağllk sorunlarından biridir. Karaciğer, vitamin D (Vit-D)'nin metabolizmast ve depolanmastnda önemli bir organdır. Vit-D’nin hücre farkllaşmast, çoğalmast ve bağısılklı modülasyon inhibisyonu da dâhil olmak üzere çok önemli bir biyolojik etkiye sahip olduğu bilinmektedir. Son zamanlarda, Vit-D düzeylerinin HBV enfeksiyonu gibi viral enfeksiyonlara karşı immün sistem ve konak yantııı etkileyebileceği düşüüulmektedir. Bu çalșmamızda amaç HBV ile enfekte bireyler ve HBV ile enfekte olmayan bireylerde Vit-D düzeyini karşılașttrıp Vit-D düzeyinin HBV replikasyonu ve hastaliğın progresyonu ile ilişkisini saptamaktır.

Materyal ve Çalıșmamız retrospektif olarak gerçekleștirilen tanımlayıcı bir çalıșma olarak tasarlanmıștır. Dicle üniversitesi Tip Fakültesi Hastanesi Enfeksiyon Hastalıkları ve Klinik Mikrobiyoloji polikliniğine $>20000 \mathrm{IU} / \mathrm{ml}$ olan 31 hasta ile HBsAg negatif ve komorbiditesi olmayan ancak halsizlik, yorgunluk șikâyeti ile polikliniğimize bașvurup vitamin-D düzeyleri bakılmış olan 45 hasta kontrol grubu olarak çalıșmamızda değerlendirmeye alınmıștır. Hastaların başlangıç, 6. ay ve 12. ay $25(\mathrm{OH})$ D düzeyleri incelenmiștir. Bu çalş̧̦ada kullanılan kit için üretici firmanın belirlediği 25 (OH) D referans araliklarl; eksik $(<10 \mu \mathrm{g} / L)$, yetersiz $(10-30 \mu \mathrm{g} / L)$ ve yeterli $(\geq 30 \mu \mathrm{g} / \mathrm{L})$ șeklinde belirtilmiştir.

Bulgular Kronik Hepatit B (KHB)'li hastalarn ortalama Vit-D düzeyi $23,37+10,71$ ug/l, kontrol grubunun ortalama Vit-D düzeyi 35,54+10,42 ug/l olarak saptanmıster (p<0,001). Bu durumda KHB'li hastalarda Vit-D düzeyi yetersiz olup kontrol grubuna göre daha düşük saptanmıştrt. Kontrol grubunun ise vitamin D düzeyi normal sınırlarda saptanmışstr. KHB'li hastaların grup içi Vit-D düzeyleri karşılaștırıldığında anlamlı bir fark saptanmamıștır. Bu çalıșmada düşük Vit-D düzeyinin yüksek viral yük ile ilișkili olmadığı sonucuna varılmıștır.

Sonuç Çalı̧̧mamızda, KHB hastalarında Vit-D düzeyi yetersiz bulunmuştur. Düşük Vit-D düzeyinin yüksek viral yük ile ilişkili olmadığı saptanmış olup detayl tasarlanmıș, prospektif ve kontrollü çalş̧malara ihtiyaç vardır. Ayrıca hastalar; Vit-D eksikliği ve yerine koyma tedavisi açısından değerlendirilmelidir. 


\section{GIIRIŞ}

Hepatit $\mathrm{B}$ virüs (HBV) enfeksiyonu halen tüm dünyada önde gelen sağlık sorunlarından biridir ${ }^{1}$. Etkili bir aşısı olmasına, tanı ve tedavi yöntemlerindeki gelişmelere rağmen önemini korumaktadır². Kronik Hepatit B (KHB) nekroinflamatuar karaciğer hastalığının gelişmesine neden olan ciddi bir tablo olarak kabul edilmektedir ${ }^{3,4}$. Karaciğerde gelişen enflamasyonun immün aracılı mekanizmalar ile geliştiği bilinmektedir ${ }^{5}$.

Karaciğer, D vitamini (Vit-D) metabolizmasında ve depolanmasında önemli bir organdır. Vit-D, kemik mineralizasyonunda rolü olan insan diyetinin önemli bir parçasıdır. Vit- D’nin hücre farklılaşması, çoğalması ve bağışıklık modülasyon inhibisyonu da dahil olmak üzere çok önemli bir biyolojik etkiye sahip olduğu gösterilmiştir6 ${ }^{6}$. Deride sentezlenen veya diyetle alınan vitamin D2 ve vitamin D3 biyolojik olarak aktif olmadığı için, vitamin D bağlayıcı protein ile karaciğere taşınır ve karaciğerdeki 25 hidroksilaz enzimi ile 25 hidroksivitamin D’ye (25(OH)D) çevrilir. Ancak vitamin D’nin aktif hale gelebilmesi için böbreklerde 1 alfa hidroksilaz enzimi ile 1,25 (OH) D’ye dönüşmesi gerekir. 1 alfa hidroksilaz enzimi Vit-D sentezinde kilit rol oynar. $25(\mathrm{OH})$ D, Vit-D’nin dolaşımdaki asıl formudur. İnaktif olan bu formun konsantrasyonu 1,25 (OH) D’nin yaklaşık 1000 katıdır $^{7}$. 1,25(OH)D vitamini ve $25(\mathrm{OH}) \mathrm{D}$ vitamini, Vit-D değerini belirlemek için kullanılan biyokimyasal testlerdir. Serum 25(OH)D, Vit-D değerleri için en uygun laboratuar testi olarak kabul edilir ve aylar öncesinden eksiklik durumunu gösterebilmektedir ${ }^{8}$.

Vit-D eksikliğinin artmış otoimmünite ve enfeksiyonlara duyarlılık ile ilişkili olduğu bilinmektedir ${ }^{9}$ Son zamanlarda, Vit-D’nin viral hepatitte rol oynadığı belirtilmektedir. Vit-D’nin viral hepatit patogenezindeki rolü tam olarak bilinmemektedir ancak Vit-D’nin hem doğal hem de adaptif bağışıklık sistemlerinin aktivasyonuna ve düzenlenmesine katılımının, aynı zamanda antiproliferatif etkisinin de karaciğer hastalıklarında önemini açıklayabileceği görülmektedir $^{10,11}$. Gelecekteki çalışmalarla kanıtlanmaya ihti- yaç duyulan Vit-D metabolizması ve HBV replikasyonu arasındaki olası nedensel ilişki, KHB tedavisinde cazip terapötik firsatlar sunabilir ${ }^{12}$.

Vit-D’nin kronik HBV seyri üzerindeki etkisini net olarak gösterebilmek için daha detaylı tasarlanmış, geniş serili çalışmalara ihtiyaç vardır.

$\mathrm{Bu}$ çalışmanın amacı, kronik hepatit B hastalarında Vit-D düzeylerini belirlemek ve Vit-D’nin kronik HBV seyri üzerindeki etkisini net olarak gösterebilmek için daha detaylı tasarlanmış, geniş serili çalışmalara katkı sunmaktır. Böylelikle, gelecekteki çalışmalarla kanıtlanmaya ihtiyaç duyulan Vit-D metabolizması ve HBV replikasyonu arasındaki olası nedensel ilişki, KHB tedavisinde cazip terapötik firsatlar sunabilir.

\section{GEREÇ ve YÖNTEM}

$\mathrm{Bu}$ çalışma retrospektif olarak gerçekleştirilen tanımlayıcı bir çalışma olarak tasarlanmıştır. Dicle Üniversitesi Tıp Fakültesi Hastanesi Enfeksiyon Hastalıkları ve Klinik Mikrobiyoloji polikliniğine 1 Ocak 2014- 31 Aralık 2015 tarihleri arasında başvuran hastalar içerisinde 4 grup hastanın vit-D seviyelerinin karşılaştırılması amaçlanmıştır. Vit-D immünmodulatör bir marker olarak birimin hasta takip protokolünde rutin olarak ve hasta takibine göre ihtiyaç durumunda tekrarlanarak bakılmaktadır. Çalışma periyodu içerinde hastane bilgi sistemi verilerinden Enfeksiyon Hastalıkları ve Klinik Mikrobiyoloji polikliniğine başvuran hastalar içerisinde Vit-D düzeyi çalışılan 1355 hasta çalışmaya uygunluk açısından değerlendirilmiştir. Bu hastalar içerisinde belirlenen 4 grup şu şekilde oluşturulmuştur:

1.Grup: HBsAg negatif olup başka bir komorbiditesi olmayan ancak halsizlik, yorgunluk şikayeti gibi spesifik olmayan semptomlar ile poliklinik başvurusunda bulunan vitamin D düzeyleri bakılmış olan 45 hasta, kontrol grubu olarak belirlenmiştir.

2. Grup: HBsAg pozitif ve HBV DNA'sı negatif 29 hasta 3.Grup: HBsAg pozitif ve HBV DNA 's1 2000-20000 IU/ 
ml olan 30 hasta

4.Grup: HBsAg pozitif ve HBV DNA'sı > $20000 \mathrm{IU} / \mathrm{lm}$ olan 31 hasta olgu grupları olarak belirlenmiştir.

Daha sonraki süreçte bu hastaların başlangıç, 6. ay ve 12 . ay $25(\mathrm{OH}) \mathrm{D}$ düzeyleri incelenmiştir. Çalışma, Dicle Üniversitesi Tıp Fakültesi Girişimsel Olmayan Klinik Araştırmalar Etik Kurulundan onay almıştır (26/02/2016 tarih, etik kurul no:109).

Çalışmaya dahil edilen hastaların dahil edilme ve hariç bırakma kriterleri şu şekilde belirlenmiştir:

Çalışmaya dahil edilme kriterleri;

- 18-65 yaş arası HBsAg pozitif bireyler

- HBsAg'si negatif komorbiditesi olmayan bireyler

- HBeAg pozitif olan bireyler

Çalışmadan dışlanma kriterleri;

- HBsAg negatifliği ile başka bir kronik hastalığı olanlar.

- $\quad$ HIV (Human Immunodeficieny Virus) pozitif hastalar

- Kanser hastaları

- Gebelik ve laktasyon döneminde olanlar

Hastaların yaş, cinsiyet gibi demografik verileri ve $\mathrm{HBV}$ DNA, HBsAg, HbeAg gibi HBV biyobelirteçleri, ilk başvuru anındaki $25(\mathrm{OH}) \mathrm{D}$ değerleri ile takiplerindeki 6. ve 12. aydaki $25(\mathrm{OH})$ D düzeyleri hastane bilgi sisteminden, hasta dosyaları taranarak kaydedilmiştir. HBV-DNA düzeyleri $12 \mathrm{IU} / \mathrm{ml}$ 'nin altında saptananlar negatif değer olarak kabul edilmiştir. Çalışma periyodu boyunca hasta serumunda HBsAg ve HBeAg belirteçleri enzyme-linked immunosorbent assay (ELISA) yöntemiyle çalışılmıştır. HBV DNA düzeyi kantitatif PCR yöntemiyle Roche Cobas Ampliprep kiti ile çalışılmıştır. HBV DNA birimi IU/ml olarak kullanılmıştır.
Çalışma sürecinde Vit-D ölçümü için alınan Shimatsu marka HPLC sistemine uygun, Immuchrom $\mathrm{GmbH}$ firmasına ait Immuchrom Vit- D kiti ile analiz edilmiştir.

Plazma 25(OH)D için literatürde farklı birimler kullanılmaktadır. Bu çalışmada kullanılan kit için üretici firmanın belirlediği referans aralıkları eksik, yetersiz ve yeterli şeklinde Tablo.1'de verilmiştir.

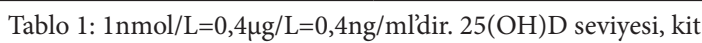
üretici firmanın normal aralıkları göz önünde bulundurularak üç şekilde kategorize edilmiştir.

\begin{tabular}{|l|l|}
\hline Eksik & $<10 \mu \mathrm{g} / \mathrm{L}$ \\
\hline Yetersiz & $10-30 \mu \mathrm{g} / \mathrm{L}$ \\
\hline Yeterli & $\geq 30 \mu \mathrm{g} / \mathrm{L}$ \\
\hline
\end{tabular}

\section{İstatistiksel analiz}

Veriler SPSS versiyon 15.0 programı ile analiz edilmiştir. Kategorik veriler sayı (n) ve yüzde (\%) değerler ile ifade edilirken, Frekans dağılımı ve yüzdeler standart yöntemler hesaplanmıștır. Kategorik verilerin analizinde Ki-Kare testi, Numerik verilerde ise gruplar arası karşılaştırmada Kruskal Wallis testi, grup içi karşılaştırmada Mann Whitney $\mathrm{U}$ testi uygulanmış olup $\mathrm{p}<0.05$ değeri istatistiksel olarak anlamlı olarak kabul edilmiş ve analiz sonuçları bu değere göre yorumlanmıştır.

\section{BULGULAR}

Hastaların 77'si erkek (\%57), 58'i kadındı (\%43) ( $\mathrm{p}=0,812)$. Kadın ve erkek hastalar arasında başlangıç, 6.ay ve 12. ay Vit-D düzeyleri arasında anlamlı bir fark saptanmamıştır (Tablo 2).

\begin{tabular}{|l|c|c|c|c|c|}
\hline \multicolumn{6}{|c|}{ Tablo 2: Kadın ve erkek ortalama D vitamini düzeyleri } \\
\hline & Cinsiyet & Sayı & Ortalama & $\begin{array}{c}\text { Std. } \\
\text { Deviation }\end{array}$ & P değeri \\
\hline \multirow{2}{*}{ Başlangıç } & Erkek & 77 & 29,2468 & 15,441 & \multirow{2}{*}{0,133} \\
\cline { 2 - 5 } & Kadın & 58 & 25,569 & 11,7848 & \\
\hline \multirow{2}{*}{ 6. ay } & Erkek & 77 & 28,4935 & 13,1935 & \multirow{2}{*}{0,319} \\
\cline { 2 - 5 } & Kadın & 58 & 26,3276 & 11,3623 & \\
\hline 12. ay & Erkek & 77 & 28,3766 & 14,0797 & 0,212 \\
\hline
\end{tabular}


J Biotechnol and Strategic Health Res. 2021;5(1):57-64

İNCE, ÇELEN, İNCE, KALKAN, Chronic Hepatitis B and Vitamin D

Her üç dönemde de en düşük ortalama Vit-D düzeyi 3. grupta saptanmıştır. İkinci ve 4. grupta Vit-D düzeyi yetersiz düzeyde olup kontrol grubunun Vit-D düzeyi ise düzeyde saptanmıştır (Tablo 3)

\begin{tabular}{|c|c|c|c|c|c|}
\hline \multicolumn{2}{|l|}{ Grup } & Yaş & Bazal & 6. ay & 12. ay \\
\hline \multirow{3}{*}{ Grup 1} & Ortalama & 41,8889 & 35,1556 & 35,6889 & 35,7778 \\
\hline & Sayı & 45 & 45 & 45 & 45 \\
\hline & std. deviasyon & 13,64355 & 12,82568 & 12,8573 & 14,46609 \\
\hline \multirow{3}{*}{ Grup 2} & Ortalama & 40,2258 & 29,0000 & 26,1935 & 25,9677 \\
\hline & Sayı & 31 & 31 & 31 & 31 \\
\hline & std. deviasyon & 13,44299 & 13,16561 & 7,93061 & 10,88878 \\
\hline \multirow{3}{*}{ Grup 3} & Ortalama & 36,6897 & 19,5172 & 20,1724 & 19,7241 \\
\hline & Sayı & 29 & 29 & 29 & 29 \\
\hline & std. deviasyon & 12,87329 & 9,94133 & 9,65501 & 10,0424 \\
\hline \multirow{3}{*}{ Grup 4} & Ortalama & 43,8000 & 22,9333 & 23,9333 & 22,2000 \\
\hline & Sayı & 30 & 30 & 30 & 30 \\
\hline & std. deviasyon & 12,42467 & 14,50549 & 11,69124 & 13,55042 \\
\hline \multirow{3}{*}{ Total } & Ortalama & 40,8148 & 27,6667 & 27,5630 & 27,0593 \\
\hline & Sayı & 135 & 135 & 135 & 135 \\
\hline & & 13,25760 & 14,05851 & 12,44187 & 14,09973 \\
\hline & & & $\mathrm{p}<0,001$ & $\mathrm{p}<0,001$ & $\mathrm{p}<0,001$ \\
\hline
\end{tabular}

Totalde tüm gruplarda plazma 25(OH)D seviyesi 12 $(\% 8,9)$ kişide eksiklik, 73 (\%54,1) kişide yetersizlik düzeyinde olup, Vit-D 50 (\%37) kişide yeterli seviyede saptanmıştır (Tablo 4).

\begin{tabular}{|c|c|c|c|c|c|c|c|}
\hline \multicolumn{8}{|c|}{ Tablo 4: Grup içi 25(OH)D oranları } \\
\hline & & & \multicolumn{4}{|c|}{ Grup } & \multirow{2}{*}{ Total } \\
\hline & & & Grup 1 & Grup 2 & Grup 3 & Grup 4 & \\
\hline \multirow{6}{*}{ Vit-D } & \multirow{2}{*}{ Eksik } & Sayı & 0 & 2 & 4 & 6 & 12 \\
\hline & & $\%$ & $0,00 \%$ & $6,50 \%$ & $13,80 \%$ & $20,00 \%$ & $8,90 \%$ \\
\hline & \multirow{2}{*}{ Yetersiz } & Sayı & 20 & 16 & 20 & 17 & 73 \\
\hline & & $\%$ & $44,40 \%$ & $51,60 \%$ & $69,00 \%$ & $56,70 \%$ & $54,10 \%$ \\
\hline & \multirow{2}{*}{ Yeterli } & Sayı & 25 & 13 & 5 & 7 & 50 \\
\hline & & & $55,60 \%$ & $41,90 \%$ & $17,20 \%$ & $23,30 \%$ & $37,00 \%$ \\
\hline \multirow{2}{*}{\multicolumn{2}{|c|}{ Total }} & Sayı & 45 & 31 & 29 & 30 & 135 \\
\hline & & $\%$ & $100,00 \%$ & $100,00 \%$ & $100,00 \%$ & $100,00 \%$ & $100,00 \%$ \\
\hline
\end{tabular}


2., 3. ve 4. gruptaki Vit-D düzeyi $23,37 \pm 10,71 \mu \mathrm{g} / \mathrm{l}$, kontrol grubunun ortalama Vit-D düzeyi $35,54 \pm 10,42 \mu \mathrm{g} / \mathrm{l}$ olarak saptanmıştır $(\mathrm{p}<0,001)$. Bu durumda KHB’li hastalarda Vit-D düzeyi yetersiz olup kontrol grubuna göre daha düşük saptanmıştır. Kontrol grubunun ise Vit-D düzeyleri yeterli düzeyde saptanmıştır (Tablo 5).

\begin{tabular}{|c|c|c|c|c|c|}
\hline \multicolumn{2}{|l|}{ Grup } & Sayı & Ortalama & Std. Deviation & P değeri \\
\hline \multirow{2}{*}{ Başlangıç } & Kontrol Grubu & 45 & 35,1556 & 12,8257 & \multirow{2}{*}{$<0,001$} \\
\hline & Olgu Grubu & 90 & 23,9222 & 13,18 & \\
\hline \multirow{2}{*}{ 6. ay } & Kontrol Grubu & 45 & 35,6889 & 12,8573 & \multirow{2}{*}{$<0.001$} \\
\hline & Olgu Grubu & 90 & 23,5000 & 10,0630 & \\
\hline \multirow{2}{*}{ 12. ay } & Kontrol Grubu & 45 & 35,7778 & 14,4661 & \multirow{2}{*}{$<0.001$} \\
\hline & Olgu Grubu & 90 & 22,7000 & 11,7564 & \\
\hline \multirow{2}{*}{ Üçünün Ortalaması } & Kontrol Grubu & 45 & 35,5407 & 10,4200 & \multirow{2}{*}{$<0.001$} \\
\hline & Olgu Grubu & 90 & 23,3741 & 10,7127 & \\
\hline
\end{tabular}

Kontrol grubunun Vit-D düzeyleri üç dönemde de yeterli düzeyde ve diğer gruplara göre de daha yüksek seviyede saptanmıştır. Diğer üç grubun Vit-D düzeyi arasında anlamlı fark saptanmamıştır (Tablo 6).

\begin{tabular}{|l|c|c|c|}
\hline \multicolumn{1}{|l|}{$\begin{array}{l}\text { Tablo 6: Aylara göre grup içi } 25(\mathrm{OH}) \\
\text { karşılaştırması ve p değerleri }\end{array}$} & $\begin{array}{c}\text { bazal } \\
\text { p değeri }\end{array}$ & $\begin{array}{c}\text { 6. ay } \\
\text { p değeri }\end{array}$ & $\begin{array}{c}\text { 12. ay } \\
\text { p değeri }\end{array}$ \\
\hline 1. grup - 2. grup & 0.051 & 0.002 & 0.003 \\
\hline 1. grup - 3. grup & $<0.001$ & $<0.001$ & $<0.001$ \\
\hline 1. grup - 4. grup & $<0.001$ & $<0.001$ & $<0.001$ \\
\hline 2. grup - 3. grup & 0.003 & 0.023 & 0.058 \\
\hline 2. grup - 4. grup & 0.051 & 0.354 & 0.137 \\
\hline 3. grup - 4. grup & 0.387 & 0.244 & 0.727 \\
\hline
\end{tabular}

\section{TARTIŞMA ve SONUÇ}

Kronik karaciğer hastalığında vitamin D eksikliği prevelansı \%64-92 arasında bildirilmiştir. Prevelansının oldukça yüksek olmasının yanında hastalık şiddetiyle negatif yönde ilişkili bulunmuştur. Önceleri sadece kolestatik etiyolojideki karaciğer hastalığında düşük olduğu düşünülmekteydi, ancak sonrasında kronik karaciğer hastalığında vitamin D eksikliğinin tüm etiyolojilerde sık olduğu anlaŞılmıştır ${ }^{13}$.
Tüm bu bilgiler ışı̆̆ında halen kesin olmayan veri ise, kronik karaciğer hastalarında Vit-D tedaviye ilave edildiği zaman tedavi başarısına nasıl bir katkı sağlayacağıdır. Gerek bizim, gerekse önceki çalışmalarda belirtildiği gibi Vit-D nin sentez basamaklarında karaciğer önemli bir yer tutar. Karaciğer, Vit-D sentezinde çok önemli bir organdır; 25-hidroksilasyon burada meydana gelir ve Vit-D bağlayan protein büyük oranda burada sentezlenir ${ }^{14}$.

Vit-D eksikliği kronik karaciğger hastalığg olanlar arasında yaygındır. Bir çalışmada, düşük Vit-D durumu, kronik karaciğer yetmezliği olan hastalarda karaciğer dekompansasyonu ve mortalitenin belirleyicisi olarak bulunmuştur. Yeni bir çalışma, Vit-D hepatik stellat hücrelerinde tip I kollajen oluşumunu önlediğini bulmuştur. $\mathrm{Bu}$ nedenle Vit-D eksikliğinin düzeltilmesi karaciğer fibrozisini engellemek için potansiyel bir hedef olabilir ${ }^{15}$.

Literatür tarandığında Vit-D ve kronik hepatit ilişkisi konusundaki çalışmaların büyük bir kısmının KHC hastaları ile yapıldığı görülmüştür. KHB ve Vit-D ilişkisi konusunda az sayıda yapılmış çalışmaların birinde kronik hepatit B hastalarının şiddetli Vit-D eksikliğiyle karşı karşıya ol- 
dukları belirtilmiştir ${ }^{16}$. Bir başka ifadeyle kronik karaciğer hastalıklarında gelişen Vit-D eksikliğinin bütün bu olaylar için neden mi yoksa sonuç mu olduğu tam belli değildir. Plazma 25(OH)D düzeyleri $10 \mu \mathrm{g} / \mathrm{l}$ 'nin (25 nmol/l) altında ise nitelikli olarak eksik ve $30 \mu \mathrm{g} / \mathrm{l}$ 'nin $(75 \mathrm{nmol} / \mathrm{l})$ altında ise nitelikli olarak yetersiz ya da suboptimal olduğu konusunda görüş birliği vardır ${ }^{17}$.

Viral yük ile Vit-D ilişkisine bakılan bir çalışmada, KHB hastalarında HBV DNA $(\log 10 \mathrm{IU} / \mathrm{ml})$ düşük 25(OH)D serum düzeylerinin güçlü bir belirleyicisi olarak bulunmuş, ortalama 25(OH)D serum konsantrasyonları HBV DNA <2,000 IU/ml; 17ng/ml, >2,000 IU/ml; 11ng/ml olarak tespit edilmiştir ${ }^{18}$. Bizim çalışmamızda KHB'li hastaların grup içi Vit-D düzeyleri karşılaştırıldığında anlamlı bir fark saptanmamıştır. Bu durumda bizim çalışmamızda düşük Vit-D düzeyinin yüksek viral yük ile ilişkili olmadığı sonucuna varılmıştır (Tablo 6). Ancak hasta sayımızın az olması, hastalarımızın 3 dönemde Vit-D düzeylerine bakılmış olması ve bazı hastaların viral yükü yüksek ancak HBeAg pozitif kronik enfeksiyon fazda olmaları sebebiyle bu sonuca varılmış olabilir.

Ulu ve ark. ${ }^{19}$ yaptığ 1 bir çalışmada $90 \mathrm{KHB}$ hastası ve 76 kontrol grubunun Vit-D düzeyleri karşılaştırılmış ve kontrol grubunun Vit-D düzeyleri sırasiyla $11,7 \pm 6,6 \mathrm{ng} / \mathrm{ml}$ ile $16,2 \pm 8,7 \mathrm{ng} / \mathrm{ml}$ olarak saptanmıştır. Olgu kontrol düzeni ile tasarlanmış olan bu çalışmada Vit-D düzeyleri KHB'li hastalarda daha düşük bulunmuştur. Kadın erkek arasında Vit-D düzeyi açısından anlamlı bir fark saptanmamıştır. Viral yük ile düşük Vit-D düzeyi arasında da bir korelasyon saptanmamıştır. Bizim çalışmamız da benzer bir şekilde olgu kontrol düzeni ile yapılmış olup olgu grubunun Vit-D düzeyi 23,37 $\pm 10,71 \mu \mathrm{g} / \mathrm{l}$, kontrol grubunun Vit-D düzeyi ise $35,54 \pm 10,42 \mu \mathrm{g} / \mathrm{l}$ olarak saptanmıştır. KHB'li hastaların Vit-D düzeyleri yetersiz düzeyde olup kontrol grubuna göre daha düşük seviyede tespit edilmiştir (Tablo 5). Ulu ve ark. çalışmasındaki gibi bizim de çalışmamızda kadın ve erkek arasında Vit-D düzeyi açısından anlamlı bir fark saptanmamış olup (p:0,428) (Tablo 2), viral yük ile düşük Vit-D düzeyi arasında korelasyon saptanmamıştır (Tablo 6).

Bizim çalışmamızdakine benzer şekilde KHB'li hastalarda kontrol grubuna göre daha düşük Vit-D düzeyi saptanan çalışmalardan birinde 128 naif KHB hastası ve 128 kontrol grubunun Vit-D düzeyi analiz edilmiştir. KHB hastalarında $25(\mathrm{OH})$ D3 düzeyi kontrol grubuna göre daha düşük düzeyde tespit edilmiştir ${ }^{20}$.

Yine ülkemizde yapılan bir çalışmada $35 \mathrm{KHB}$ 'li hasta (Grup 1), 30 doğal bağışıklı birey (2.Grup), 30 sağlıklı yetişkinin (3. grup) Vit-D düzeyleri karşılaştırılmıştır. Grup 1'deki hastaların 25(OH)D düzeyleri diğer gruptakilere

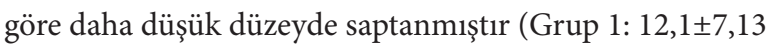
ng/ml, Grup 2: 7,65 $\pm 4,19$ ng/ml ve Grup 3: 14,17 $\pm 9,18$ ng/ $\mathrm{ml})(\mathrm{p}<0.001)^{21}$.

Mısır'da 2015 yılında yapılan prospektif bir çalışmada 96 HBeAg negatif KHB hastası ve 25 kontrol grubunun Vit-D düzeyi analiz edilmiştir.KHB hastaları inaktif evre ve kronik hepatit evresi olmak üzere iki gruba ayrılmış olup kontrol grubu ile Vit-D düzeyleri karşılaştırılmıştır. Çalışma sonucunda KHB hastalarında Vİt-D düzeyi daha düşük saptanmış olup D vitamini düzeyleri HBV DNA düzeyleri ile güçlü bir negatif korelasyona sahip bulunmuş$\operatorname{tur}^{22}$.

Plazma Vit-D düzeyleri mevsimsel değişim göstermektedir. Ancak bizim çalışmamızda hastaların Vit-D düzeyleri tek seferlik ölçülmeyip bazal, 6 . ay ve 12 . ayda da takip edildiği için böyle bir mevsimsel değişikliğe yer vermedik.

Sonuç olarak KHB hastalarında Vit-D düzeyi yetersiz olabilmektedir. Bu hastalar Vit-D eksikliği ve takviye gerekliliği açısından değerlendirilmelidir. Hangisinin sebep hangisinin sonuç olduğu, antiviral tedaviye vitamin eklenmesinin ne derecede faydalı olacağı konusunda daha kapsamlı çalışmalara ihtiyaç vardır. Düşük Vit-D düzeyinin yüksek viral yük ile ilişkili olup olmadığını saptamak için 
J Biotechnol and Strategic Health Res. 2021;5(1):57-64

çok sayıda hastada prospektif çalışmalar yapılmalıdır. Yapilacak bu çalışmalar doğrultusunda Vit-D replasmanının

KHB'deki yeri daha iyi anlaşılacaktır. 
J Biotechnol and Strategic Health Res. 2021;5(1):57-64

\section{Kaynaklar}

1. Perz JF, Armstrong GL, Farrington LA, et al.The contribution of hepatitis B and hepatitis C virus infection to cirrhosis and primary liver cancer worldwide.J Hepatol. 2006;45 (4):529-538. doi: 10.1016 / j.jhep.2006.05.013

2. Koziel MJ,Siddiqui A. Hepatitis B viruses and Hepatitis delta viruses,Mandell GL,Bennet JE,Dolin R(eds).Principles and Practice of Infectious Diseases.6th ed.Philadelphia,Churchil Livingstone.2005:1864-90

3. Brunetto MR, Oliveri F, Colombatto P, et al. Hepatitis B surface antigen serum levels help to distinguish active from inactive hepatitis B virus genotype D carriers. Gastroenterology. 2010;139(2):483-90. doi:10.1053/j.gastro.2010.04.052

4. Mohamadkhani A, Katoonizadeh A, Poustchi H. Immune-Regulatory Events in the Clearance of HBsAg in Chronic Hepatitis B: Focuses on HLA-DP. Middle East J Dig Dis. 2015;7(1):5-13.

5. Ganem D, Prince AM. Hepatitis B virus infection natural history and clinical consequences. N Engl J Med 2004;350:1118-1129.doi:10.1056/NEJMra031087

6. Kitson MT, Roberts SK. D-livering the message: the importance of vitamin D status in chronic liver disease. J Hepatol. 2012; 57: 897-909. doi10.1016/j.jhep.2012.04.033

7. Malham M, Jørgensen SP, Ott P, et al. Vitamin D deficiency in cirrhosis relates to liver dysfunction rather than Aetiology. World J Gastroenterol 2011;17:922-925. doi: 10.3748 / wjg.v17.i7.922.

8. Holick MF. Vitamin D status: measurement, interpretation, and clinical application. Ann Epidemiol. 2009;19:73-8. doi: 10.1016 / j.annepidem.2007.12.001.

9. Miragliotta G., Miragliotta L. Vitamin D and infectious diseases. Endocr Metab Immune Disord Drug Targets. 2014;14(4):267-71. doi: 10.2174 / 1871530314666141027102627.

10. Chen E. Q., Shi Y., Tang H. New insight of vitamin D in chronic liver diseases. Hepatobiliary Pancreat Dis Int. 2014;13: 580-585. doi.org/10.1016/S1499-3872(14)60295-2

11. Iruzubieta P., Teran A., Crespo J. et al. Vitamin D deficiency in chronic liver disease. World J Hepatol. 6, 901-915 (2014). doi:10.4254/wjh.v6.i12.901

12. Martineau AR, Timms PM, Bothamley GH, et al. High-dose vitamin D(3) during intensive-phase antimicrobial treatment of pulmonary tuberculosis: a double-blind randomised controlled trial. Lancet 2011;377:242-250. doi:10.1016/S0140-6736(10)61889-2

13. Stokes CS, Volmer DA, Grunhage F, et al. Vitamin D in chronic liver disease. Liver Int 2013;33(3):338-52.

14. Rahman AH, Branch AD. Vitamin D for your patients with chronic hepatitis C. Journal of Hepatology 2013;58 j:184-189. doi:10.1016/j.jhep.2012.07.026

15. Skaaby T, Husemoen LSN, Borglykke A, et al. Vitamin D status, liver enzymes, and incident liver disease and mortality: a general population study.published online november 2013 in Springer Science Business Media New York 2013; doi:10.1007/s12020-013-0107-

16. Kong J, Ding Y, Zhang C, et al. Severe Vitamin D-Deficiency and Increased Bone Turnover in Patients with Hepatitis B from Northeastern China. Endocrine Research 2013;38(4):215-222. doi: 10.3109 / 07435800.2013.768266

17. Fulgencio MG, Garc1'a-Alvarez M, Berenguer J, et al. Vitamin D deficiency is associated with severity of liver disease in HIV/HCV coinfected patients. Journal of Infection 2013;1-9.doi:10.1016/j.jinf.2013.10.011

18. Farnik H, Bojunga J, Berger A, et al. Low Vitamin D Serum Concentration Is Associated With High Levels of Hepatitis B virüs Replication in Chronically Infected Patients. Hepatology 2013;58:1270-1276.doi:10.1002/hep.26488

19. Candevir Ulu A.,Kuşçu F.,Inal A.S.,Vitamin D Levels and Hepatitis B:Is There Any Rela tionship?,Viral Hepat J 2015;21:44-47

20. Chen EQ, Bai L, Zhou TY, et al. Sustained suppression of viral replication in improving vitamin D serum concentrations in patients with chronic hepatitis B. Sci Rep.2015;5:15441. doi: 10.1038/srep15441.

21. Demir C, Demir M. Vitamin D levels in patients with chronic hepatitis B virus infection and naturally immunized individuals. Int Med Ins J. 2013;1(1):2. doi: 10.7243/2052-6954$1-2$.

22. Ebada Said, Waleed El Agawy, Rehab Ahmed, et al. Serum Vitamin D Levels in Treatment-naïve Chronic Hepatitis B Patients. J Transl Int Med. 2017; 5(4): 230-234. doi: 10.1515 / jtim- 2017- 0038 